\title{
THE PHYSICAL COMPETENCE OF FUTURE TEACHERS AS AN INPUT TOWARDS THE QUALITY OF THE PEDAGOGICAL ACTIVITY CONCEPT
}

\author{
Helena Vecenane \\ Liepaja University, Latvia \\ Dina Bethere \\ Liepaja University, Latvia \\ Svetlana Usca \\ Rezekne Academy of Technologies, Latvia
}

\begin{abstract}
The indicators of physical competence in scientific research studies and normative documents of education systems are defined differently. However, the consolidation of research evidence confirms that in this area the knowledge and skills of the person imply taking responsibility for health and well-being of one's body, motoric skills, and ability to regulate and physically adapt to the surrounding environment.

Undoubtedly, the family plays a major role in the development of children's physical competence. At the same time in this context the input of educational programmes is significant together with the individual physical competence of a teacher and his/her understanding about how to ensure its quality in one's own work and in the concept of educational system.

The aim of the research reflected in this publication is to analyse the physical competence of the students of Teacher Programmes as a resource for the development of the concept of their further pedagogical work. For this purpose, the emerging teachers have been surveyed using the methodology developed by Corbin et al. (2008). For statistical analysis of the research data the SPSS 22.0 programme was employed: a method of descriptive statistics, Kruskal-Wallis test, and Kendall's tau-b correlation test.
\end{abstract}

Keywords: physical competence, physical activities, dietary habits, pedagogical concept.

\section{Introduction}

The findings and data presented in this publication are part of a broader study devoted to the problem of healthy lifestyle development for children and young people. The research initiative is based on analysis of two interrelated trends: the deterioration of the health status of children and young people and the support provided by the education system to overcome these problems.

The research field reflected in this publication is internationally significant already for a long time. It is reflected, for example, in the report of World Health Organization (WHO) which states that in most countries the major risk factors 
accounting for a significant proportion of all deaths and disease are overweight and obesity and physical inactivity (WHO, 2002). In 2003, WHO Global Strategy on Diet, Physical Activity and Health is issued for guiding activity development at local, national and international levels in this way intending to reduce the risk factors related to diet and physical activity in populations (WHO global strategy on diet, physical activity and health, 2003).

The problem of implementing a healthy lifestyle has maintained its topicality up to today. This is evidenced by the strategic priorities of both WHO and UNESCO, which state that all children and young people must have access to safe, inclusive, health-promoting learning environments. Therefore, school policies and programmes should support the adoption of healthy diets and physical activity through nutrition education, nutrition programmes in schools, inclusive physical education and creating a supportive environment (WHO, 2016; UNESCO strategy on education for health and well-being, 2016).

The above mentioned tendencies also influence the strategic planning of Latvian social environment and education system development. At present, in the National Development Plan for 2014-2020, Strategic objective "Healthy and fit for work" it is emphasized that one of the priorities is to strengthen healthy lifestyle in society as a whole supporting health promotion networks through: (1) promotion of healthy nutrition, active lifestyle and mental health (2) development of children's and youth sports and national sports, (3) inclusion of health education in school curricula, (4) prevention of addictive substances and processes (Latvijas Nacionālais attīstības plāns 2014.-2020. gadam, 2012: 46.-48.).

Policies determine that pedagogical concepts of educational institutions should promote good nutrition and physical activity through strengthening school links with nutrition, youth, sports and other relevant programmes and with communities.

One of healthy lifestyle aspects is physical competence. It includes knowledge and skills related to the promotion of healthy lifestyle. In this regard, for example, in the Public Health Review of United Kingdom (Gatineau \&Den, 2011), analysing the dietary and physical activity habits in England, the authors conclude that the knowledge and attitude are the key elements in the development of a positive health behaviour.

Sometimes the physical competence is defined as one's overall perception of personal physical abilities. Thereby perceived physical competence is a subjective perception of physical abilities, and these perceptions may or may not coincide with the actual ability. Perceived physical competence is considered to be the more as a global construct of physical self-efficacy, therefore it is considered to be the people's overall perception of their general physical abilities on physical tasks (Bell, 1997; Hänsel et al., 2016). Similar understanding of physical 
competence is revealed also through concept of physical literacy, which implies motivation, confidence, physical competence, knowledge and understanding of the value of taking responsibility for the engagement in physical activities for life (Canada's physical literacy consensus statement, 2015).

In the broader view, the structure of physical competence includes (1) taking responsibility for personal health and well-being of the body, (2) motor skills, abilities, (3) ability to physically adapt to the environment (Der Bayrische Bildungs- und Erziehungsplan, 2006).

Similar approaches related to the structure of pupils' physical literacy are also included in the strategic planning documents of educational content in Latvia. In this context physical literacy involves: (1) learning the key movement skills; (2) a person's responsible involvement in a variety of physical activities that promote health and life skills; (3) acquiring skills for planning and evaluating new and creative physical activities and events, promoting mental and physical abilities; (4) ability to demonstrate leadership and collaboration skills by working in groups or teams (Vīzija par skolēnu kādam tam jābūt, 2017).

Consequently, a complete picture of healthy lifestyle and physical competence is needed for both qualified and emerging teachers, which could serve as a basis for further professional activity in the field of education.

Taking into account the urgency of the healthy lifestyle implementation issues, the aim of this study is to analyse the physical competence of the students of teacher programmes as a resource for developing the concept of further pedagogical activity.

The following research questions have been put forward:

Research Question 1: Which indicators form the structure of future teachers' physical competence?

Research Question 2: How are the skills, which contribute to the quality of the pedagogical concept in conjunction with the development of physical competence, demonstrated?

The questionnaire developed by C. Corbin (Corbin et al., 2008) is employed in this study emphasizing two of the basic healthy lifestyle and physical competence components - physical activity and dietary habits.

\section{Methodology}

\section{The research context}

As previously indicated, the data summarized in this study is part of a broader research devoted to the issues of healthy lifestyle development for children and young people. The research initiative is based on the data collected in Latvia, which testify the restrictions of physical competence development for children and young people in different age groups. 
In this regard, the data from the study on sports habits of Latvian people confirm that in $88 \%$ of cases the pupils aged 6-13 engage in sports activities as well as attend various art or interest related classes. Accordingly, $95 \%$ of adolescents aged 13-17 are engaged in sports. However, only $5 \%$ of representatives of this group participate in these sports activities on average once a week (Slimību profilakses un kontroles centrs, 2012).

The data on sports habits of Latvian youth reveal comparatively controversial indicators. The survey results show that young people, age 13-25, mostly spend their spare time passively: $64 \%$ - on the computer, $40 \%$ - watching television programs, $30 \%$ - reading. On the other hand, participation in sports activities is confirmed by $53 \%$ of respondents (Slimību profilakses un kontroles centrs, 2014).

The analysis of data on the health status of children and adolescents in 2016 confirms that $34.5 \%$ of the first-grade pupils and $36.5 \%$ of adolescents fall under the $2^{\text {nd }}$ health group, which is characterized by, for example, developing threats of chronic diseases and functional disorders. Approximately $3.5 \%$ of children and adolescents in each age group comply with the $3^{\text {rd }}$ health group characterized by a decompensatory stage, hereditary organ or system pathology, functional pathology and weight disorders. In addition, the posture problems are diagnosed for $13.9 \%$ of the first graders and $15.4 \%$ of the 1,000 examined cases (Central statistical bureau of Latvia, 2017).

In 2016, in the context of students' understanding of a healthy lifestyle, summarizing the questionnaire data in the group of student respondents $(\mathrm{N}=129)$ it is concluded that $88.5 \%$ of respondents have to change their dietary habits and that the physical activity of students is insufficient. Students see the following obstacles for implementation of a healthy lifestyle: laziness and the lack of willpower - $68.4 \%$, the rapidness of life's rhythm - $49 \%$, the lack of finances $34.7 \%$, the lack of support from surrounding people - $33.7 \%$, harmful habits $19.4 \%$, insufficient knowledge - $10.2 \%$, stress - $5 \%$, diseases - $5.1 \%$ (Vecenāne, 2016).

\section{Participants}

The respondent group for this research consists of Liepaja University students - future teachers $(\mathrm{N}=186)$ taking into account their different age, chosen field and experience. From all respondents $87.6 \%$ are female and $2.4 \%$ - male. The age of respondents: 18-25 y/o - 55.4 \%, 26-35y/o - $18.8 \%$, 36-45 y/o - 17.7 $\%$, 46-55 y/o - $7.5 \%$, and $0.6 \%$ of respondents older than 55 years. The respondents are majoring in different fields: basic education teacher - $34.8 \%$, preschool teacher - $28.5 \%$, sports teacher - $12.4 \%$, special education teacher - 8.1 $\%$, music teacher $-4.3 \%$, history teacher $-3.8 \%$, and $8.1 \%$ of the respondents have not specified their field. 


\section{Research procedure and design}

This study employs a questionnaire developed by C. Corbin (Corbin et al., 2008) integrating two indicator systems related to the individual's physical activity and dietary habits (Cronbach's Alpha $=0.778$ ). The questionnaire consists of twenty questions. For the research purposes the two groups of indicators are set apart: (1) indicators characterizing the structure of physical competence of future teachers (research question 1), (2) indicators that confirm the respondent's skills to contribute to the quality of the pedagogical concept in conjunction with the development of physical competence (research question 2).

In relation to the structure of physical competence of future teachers, the following indicators have been assessed: (1) skills to regularly assess one's own physical fitness and dietary habits; to make regular records on physical activity and dietary habits; to set realistic goals for improvement of physical fitness and dietary habits; to develop a personal program for ensuring physical activity and healthy eating; (2) attitudes about engaging in sports activities and using a healthy diet while overcoming the obstacles; (3) abilities to ensure regularity in the perfection of physical competence.

Accordingly, keeping in mind the potential contribution of future teachers, the respondents' knowledge of the veracity of public information and their ability to involve other people in physical activity and healthy dietary habits have been assessed.

The publication summarizes the data acquired during the period of 2016 2018. For statistical analysis of the research data, the SPSS 22.0 programme was employed: a method of descriptive statistics, Kruskal-Wallis test, and Kendall's tau-b correlation test.

\section{Findings}

Analysing the data obtained in this research, the percentage of responses was calculated for each group of indicators.

Table 1 Indicators of respondents' physical competence

\begin{tabular}{|c|c|c|c|c|}
\hline \multirow[t]{2}{*}{ Indicators } & \multirow{2}{*}{$\begin{array}{l}\text { Average value } \\
\text { (Mean) }\end{array}$} & \multicolumn{3}{|l|}{$\%$} \\
\hline & & No & Partly & Yes \\
\hline Physical activities & 1.792 & 42.7 & 35.3 & 22.0 \\
\hline Healthy dietary habits & 1.681 & 48.3 & 35.3 & 16.4 \\
\hline
\end{tabular}

Here it can be added that the self-evaluation is higher for respondents who are involved in physical activities. In addition, the maximal significant differences 
$(p=0.000)$ are observed in relation to respondents' gender: the self-evaluation of males is higher than the one of females (Mean Rank 892.32).

With regards to the implementation of movement activities there are also significant differences $(\mathrm{p}=0.005)$ observed related to the age of respondents: the highest self-evaluation is for respondents aged 26 - 35 (Mean Rank 783). Accordingly, the lowest self-evaluation is for respondents over the age of 55 (Mean Rank 609.00).

The maximal significant differences $(p=0.000)$ are also found in relation to the chosen specialization: the lowest self-evaluation is for emerging history teachers (Mean Rank 687.84) and pre-school teachers (Mean Rank 693.76), but the highest - for future sports teachers (Mean Rank 1006.61).

The statistical data analysis of indicators related to healthy dietary habits revealed significant differences in terms of age $(p=0.023)$ : the self-evaluation is higher for respondents aged 26-35 (Mean Rank 209.03), but lower for respondents aged over 55 (Mean Rank 137.50). In addition, there are also significant differences related to the chosen speciality $(p=0.050)$ : the self-evaluation is higher for primary school teachers (Mean Rank 191.25), but lower for pre-school (Mean Rank 172.77) and special education teachers (Mean Rank 172.13).

The more detailed data analysis confirms the proportion of certain individual components in the structure of physical competence of respondents.

Table 2 The structure of physical competence of respondents

\begin{tabular}{|l|c|c|c|c|}
\hline \multicolumn{2}{|l|}{ Indicators } & \multicolumn{3}{c|}{ \% } \\
\cline { 3 - 5 } \multicolumn{2}{|c|}{} & No & Party & Yes \\
\hline Physical activities & Skills & 43.5 & 34.5 & 22.0 \\
\cline { 2 - 5 } & Attitudes & 41.9 & 34.4 & 23.7 \\
\cline { 2 - 5 } & Abilities & 40.3 & 41.4 & 18.3 \\
\hline \multirow{3}{*}{ Healthy eating habits } & Skills & 54.5 & 30.9 & 14.6 \\
\cline { 2 - 5 } & Attitudes & 40.9 & 40.3 & 18.8 \\
\cline { 2 - 5 } & Abilities & 32.3 & 47.3 & 20.4 \\
\hline
\end{tabular}

The statistical analysis of data on implementation of physical activities shows maximal significant differences $(p=0.000)$ with regards to gender in assessment of both skills and attitudes: in both cases the Mean Rank is higher for male (542.99 and 241.28) than for female (454.57 and 178.77) students. Accordingly, the maximal significant differences $(\mathrm{p}=0.000)$ can be observed in assessment of skills with regards to age: the highest self-evaluation is for respondents aged 26-35 (Mean Rank 494.52) and 18-25 (Mean Rank 484.39), but the lowest - for respondents aged over 55 (Mean Rank 272.60). In contrast, the maximal significant differences $(p=0.000)$ are determined also with regards to specialization when assessing skills and attitudes: the highest evaluation comes 
from future sports teachers (Mean Rank 607.73) and music teachers (Mean Rank 553.03), but the lowest - from history teachers (Mean Rank 431.81). Accordingly, when evaluating the attitudes, the highest score is for sports teachers (Mean Rank 280.07), but the lowest one for pre-school teachers (Mean Rank 165).

Data analysis in relation to healthy dietary habits identifies significant differences with regards to respondents' age when assessing their skills ( $\mathrm{p}=0.002$ ): the highest score is for respondents aged 46-55 (Mean Rank 518.23) and 25-35 (Mean Rank 515.44), but the lowest - for respondents over 55 (Mean Rank 333.40). Assessing the attitude, the highest rating is for respondents of age 25-35 (Mean Rank 221.27) and 46-55 (Mean Rank 207.93), but the lowest for respondents over the age of 55 (Mean Rank 76.50). Assessing the abilities, the highest score is observed for respondents of age 46-55 (Mean Rank 121.71), and respondents of age over 55 (Mean Rank 30.50). Significant differences $(\mathrm{p}=0.045)$ were also found with regards to the chosen speciality: the highest evaluation for skills comes from emerging music teachers (Mean Rank 570.86), followed by history teachers (Mean Rank 396.90).

Regarding the potential contribution of the respondents to the pedagogical concept, the indicators are summarized about respondents' knowledge regarding the veracity of publicly available information, as well as about the ability to involve the other people in physical activities and in formation of healthy dietary habits.

Table 3 Indicators of respondents' knowledge

\begin{tabular}{|l|c|c|c|}
\hline \multirow{2}{*}{ Indicators } & \multicolumn{3}{|c|}{$\%$} \\
\cline { 2 - 4 } & No & Partly & Yes \\
\hline Physical activities & 33.0 & 46.0 & 21.0 \\
\hline Healthy dietary habits & 33.6 & 46.5 & 19.9 \\
\hline
\end{tabular}

The statistical analysis of data in relation to physical activity shows the maximal significant differences ( $p=0.000)$ with regards to respondents' gender: the self-evaluation of male students is higher (Mean Rank 234.86) than for female students (Mean Rank 179.68). The differences are evident also for the indicators in relation to the respondents' specialization: the highest self-evaluation is for future sports teachers (Mean Rank 246.17) and music teachers (Mean Rank 218.94).

Accordingly, in relation to the potential influence on the development of healthy dietary habits of other people, the significant differences were observed with regards to respondents' age: the highest self-evaluation is for respondents aged 26-35 (Mean Rank 209.03), but the lowest for respondents over 55 years of age (Mean Rank 137.50). In turn, with regards to respondents' specialization, the 
highest self-evaluation is for future music teachers (Mean Rank 255.13), the lowest for teachers of special education (Mean Rank 172.13).

\section{Discussion and conclusions}

The research data on student's physical competence indicates insufficient competence of students when implementing physical activity and healthy dietary habits, which are the most important components of a healthy lifestyle. Scientists from around the world, such as the American team of researchers (Yahia et al., 2015), have similar research data on physical fitness of students concluding that physical activity, students' knowledge about healthy and unhealthy dietary habits, and nutritional knowledge need improvement, and saying that developing of gender-specific programs for promoting healthy lifestyle behaviours among students is recommended. Iranian scientists (Rahmati- Najarkolaei et al., 2015) conclude that the student's knowledge of the benefits of a healthy lifestyle is desirable as living in academic settings and preparing for exams that trigger stress, reduce healthy nutrition patterns and physical activity, which are the two factors associated with life quality. Therefore, the planning and evaluation of environmental health promotion interventions are proposed.

The research of another group of Iranian scientists (Azizi et al., 2011) have found that there was a positive and significant correlation between the nutrition knowledge and attitude of the female $(r=0.001$; $\operatorname{sig}=0.03)$ and male $(r=0.30$; sig $=0.03$ ) students; and a positive and significant correlation between the nutrition attitude and practices of male and female students $(\mathrm{r}=0.18$; $\operatorname{sig}=0.000)$. The researchers suggest that students should pay more attention to nutrition issues, and that the time students spend at college is suitable for learning and thus can promote nutrition knowledge and shape the attitude and practices of students. Therefore, the importance of nutrition in various college curriculums and improvement of the learning environment related to nutrition need to be emphasized on college campuses.

Previous research studies in Latvia in this field (Vecenāne, 2016) suggests that statistically reliable correlations $(p<0.05)$ were found between positive selfevaluation of students' knowledge and positive changes in physical activity habits. In turn, such statistically significant correlations have not been established between student's self-evaluation of their knowledge and their eating habits.

The results of our research show that, according to students' self-evaluation, the physical activity competence is insufficient for $42.7 \%$ of students, for $35.3 \%$ it is partially sufficient, but sufficient for $22.0 \%$ of respondents. In turn, $48.3 \%$ of students lack the competence of healthy dietary habits, it is partially satisfactory for $35.3 \%$, but sufficient for $16.4 \%$ of students. In addition, the self-evaluation 
scores of male students are higher, which may be related to a small percentage of male respondents. The lowest self-evaluation of physical competence is in the age group after 55, which could indicate the self-critical attitude of the respondents of this age group, and it may become a research question for another study. Data analysis shows a high self-evaluation of physical competence of emerging sports teachers, which of course is related to their specialization; however, the high selfevaluation of music teachers in terms of their skills and attitude in comparison to other teacher specializations invites for researching deeper the relationship between a particular specialization and physical competence, as well as involvement of its stimulating factors in pedagogical practice.

Changes in the education system of Latvia impose new requirements for teachers, and a competence approach has been introduced for the implementation of learning content, which emphasizes the promotion of pupils' health and physical activity (Vīzija par skolēnu kādam tam jābūt, 2017). Therefore, the physical competence for health promotion is required not only for sports teachers, but for teachers of all specialities because it is related to 1) teachers' own health and work capacity, and also quality of life; 2) interactions between the teachers and pupils which in turn promote the pupils’ physical competence development.

\section{References}

Azizi, M., Aghaee, N., Ebrahimi, M., \& Ranjbar, K. (2011). Nutrition knowledge, the attitude and practices of college students. Facta Universitatis. Series: Physical Education and Sport Vol. 9, No 3. 349 - 357. Downloaded from http://facta.junis.ni.ac.rs/pe/pe201103/ pe201103-12.pdf

Bell, W. K. (1997). The Relationship Between Perceived Physical Competence and the Physical Activity Patterns of Fifth and Seventh Grade Children. Virginia Polytechnic Institute. Downloaded from https://vtechworks.lib.vt.edu/handle/10919/11041

Canada's physical literacy consensus statement. (2015). Downloaded from http://physicalliteracy.ca/physical-literacy/consensus-statement/.

Central statistical bureau of Latvia. (2017). Children in Latvia: collection of statistics. Downloaded from http://www.csb.gov.lv/sites/default/files/nr_12_berni_latvija_ 2017_17_00_lv_en.pdf.

Corbin, C., Welk, G., Corbin, W., \& Welk, K. (2008). Concepts of Fitness and Wellness: A Comprehensive Lifestyle Approach. 7/e Published by McGraw-Hill, Boston, MA.

Der Bayrische Bildungs- und Erziehungsplan für Kinder in Tageseinrichtungen bis zur Einschulung. (2006). Weinheim, Basel: Beltz Verlag.

Gatineau, M., \& Den, M. (2011). Obesity and mental health.Oxford: National Obesity Observatory. Downloaded from https://khub.net/c/document_library/get_file?uuid= 18cd2173-408a-4322-b577-6aba3354b7ca\&groupId=31798783.

Hänsel, F., Baumgärtner, S. D., Kornmann, J., \& Ennigkeit, F. ( 2016). Sportpsychologie. Springer - Verlag.

Latvijas Nacionālais attīstības plāns 2014.-2020. gadam. (2012). Downloaded from https://likumi.lv/doc.php?id=253919. 
Rahmati- Najarkolaei, F., Talatappeh, D. H., \& Naghavi, S. (2015). Physical Activity and Nutrition Status in the University Students: A Mix method Study. Journal of Health Policy and Sustainable Health Vol. 2, No. 2. 201-206.

Slimību profilakses un kontroles centrs. (2012). Iedzīvotāju sportošanas paradumi. Downloaded from http://sabves.spkc.gov.lv/Lists/DatuAvoti/DispForm.aspx?ID=807.

Slimību profilakses un kontroles centrs. (2014). Latvijas jauniešu sportošanas paradumi. Downloaded from http://sabves.spkc.gov.lv/Lists/DatuAvoti/DispForm.aspx?ID=806

UNESCO Strategy on education for health and well-being: contributing to the sustainable development goals. (2016). Downloaded from http://unesdoc.unesco.org/images/ 0024/002464/246453e.pdf .

Vecenāne, H. (2016). Studentu veselīga dzīvesveida izpratnes un paradumu veidošanās mijsakarības. Downloaded from http://lspa.lv/files/students/Promotion/VECENANE_ HELENA_Promocijas_darbs.pdf.

Vīzija par skolēnu kādam tam jābūt: Veselība un fiziskās aktivitātes. Skola 2030. (2017). Downloaded from https://www.skola2030.lv/apspriesana.

WHO. (2016). Fiscal policies for diet and the prevention of noncommunicable diseases. Downloaded from http://www.who.int/dietphysicalactivity/publications/fiscal-policiesdiet-prevention/en/.

WHO global strategy on diet, physical activity and health: European regional consultation meeting report. (2003). Downloaded from http://www.who.int/dietphysicalactivity/ media/en/gscon_cs_report_euro.pdf.

WHO. (2002). World health report. Downloaded from http://www.who.int/whr/2002/en/.

Yahia, N., Wang, D., Rapley, M., \& Dey, R. (2015). Assessment of weight status, dietary habits and beliefs, physical activity, and nutritional knowledge among university students. Perspectives in Public Health, vol. 136, 4 (рp. 231-244). Downloaded from http://journals.sagepub.com/doi/abs/10.1177/1757913915609945?journalCode=rshi 